\title{
COMPARISION OF PHYSICOCHEMICAL PARAMETERS OF RAPE SEEDS APPLYING THE INFRARED SPECTROSCOPY METHOD
}

\author{
Artur PRZYWARA, Magdalena KACHEL-JAKUBOWSKA, \\ Artur KRASZKIEWICZ, Milan KOSZEL \\ Department of Machinery Exploitation and Management of Production Processes, University of Life \\ Sciences in Lublin, POLAND \\ E-mail of corresponding author: artur.przywara@up.lublin.pl
}

Keywords: infrared spectroscopy, near infrared spectroscopy, rapeseed oil, rapeseed cultivar

\begin{abstract}
Technical progression in sustainable agriculture requires the need for search more and newer analytical methods in order to reduce time of analysis and to minimize costs routine of tests for the highest accuracy of the result. Infrared (IR) and near infrared (NIR) spectroscopy provides such possibility. The paper presents a method of measuring the basic quality parameters (moisture, content of protein, fat, damage and contamination of raw material) of winter rapeseed for cultivars: Abacus, Bellevue, and Adriana+Catana concoction. Statistically significant differences resulting from various measurement systems between results obtained by means of sieve methods and infrared (IR), were observed. A three-dimensional way of measuring the seed shape used in three dimensional particle size analyzer (AWK 3D) suggests that it is more accurate than the measurement applying two-dimensional method used in the shaker with a set of sieves.
\end{abstract}

\section{INTRODUCTION}

Continuous high demand for winter rapeseed both for food and industrial production have contributed to the development of techniques providing a rapid assessment of this raw material. The pursuit of higher productivity should support the creativity and innovation of people primarily in the socio-economic sphere, including the field of science. The possibilities of testing the quality of products or raw materials dedicated for food and industrial purposes in every life aspect have advantages. Among them are: nondestructive and non-invasive analysis, short time preparation of sample for analysis, simple and fast routine procedure, high sensitivity of devices, improving labor safety, low costs etc. Winter rapeseed cultivars usually provide a higher yield than the spring ones. The average yield of seeds depend on the type of cultivars (hybrid or cross-bred lines), environmental conditions and the agronomic practices. However, the crop yields can vary between different countries in respect of the global trends (Calderini and Slafer, 1998; Nesi et al., 2008). High fat content with good-quality of proteins make this plant a valuable resource for food and oil industry (Casséus, 2009; Nesi et al., 2008). Assessment of raw materials is a very important step in quality control. This identification should certify that the raw material complies with a spectrum of quality parameters that allow its use for further storage and processing (Kachel-Jakubowska and Szpryngiel, 2006; Sujak and Kachel-Jakubowska, 2012). The most suitable rapeseed moisture without water and fat content for storage is in the range from 5 to $7 \%$. High fat content, particularly in wet and damaged seeds, is readily degraded by enzymes and oxygen from the air. Following such process free fatty acids are formed and acidity of seeds increases. It contributes to accumulation of orthophosphoric and phytic acids, free amino acids, and reactive substances, that are toxic and structurally and functionally deforming the cells (Krasucki et al., 2002). Storage of damaged seeds reduce the efficiency of the extraction process. Moreover, significantly worsens the quality of oil obtained measured with the values of acidic and peroxide numbers.

The use of near infrared spectroscopy in the identity analysis reduces the analysis time. Assessment of test raw materials using NIR spectroscopy can be done in several ways:

- comparing the shape and intensity a substance spectrum with that of 
reference standard purchased or obtained in similar conditions,

- comparing the intensity of absorbance at a particular wavelength,

- identification using the SIMCA (Soft Independent Modeling of Class Analogy) classifier (Vredenbregt et al., 2003).

The near infrared NIR $\left(14290-4000 \mathrm{~cm}^{-1}\right)$ and far infrared spectrophotometry FIR (700 $-200 \mathrm{~cm}^{-1}$ ) finds its great interest. The analysis is based on the principle proving that even a very simple molecule can have a very complicated spectrum (for the unknown sample), which is compared with the spectrum of a reference sample (Silvestein et al., 2005). The IR and NIR spectroscopy differ mainly in the range of the spectrum and a method for sample preparation. NIR analysis uses radiation from $10000-4000 \mathrm{~cm}^{-1}$, providing information on physicochemical properties and physical status of the sample. The use of spectroscopic techniques in the analysis of food products is widely applied among others to identify the quantity of determined constituents, detect falsifications, determine the botanical origin or control the quality changes in the process of heating and storage e.g. by measuring the moisture, fat and protein contents of raw materials.

The aim of the study was comparison the characteristic parameters of rapeseed such as: external dimensions, contaminants and injuries, moisture, protein and fat contents determined using the new IR and NIR spectroscopy methods with values of these characteristics obtained by traditional methods.

\section{MATERIAL AND METHODS}

Material to study consisted of $2 \mathrm{~kg}$ samples of three selected of winter rapeseed crops cultivars (Abacus; Bellevue; Adriana+Catana - concoction) carried out in 2014-2015 by individual farms located in the villages Kurów (Puławy District), Małków (Hrubieszów District) and Wólka Kańska - Kolonia (Chelm). Farms were randomly selected to eliminate any similarities between the obtained material. The selection was aimed at achieving maximum sample diversification to obtain reliable results between methods under consideration.

The obtained samples of research material were stored in laboratory conditions, hermetically sealed in plastic bags in order to compensate the seed moisture at a constant ambient temperature of $20^{\circ} \mathrm{C}$. Moisture analysis for comparative purposes was carried out applying common methods that use moisture analyzer (manufacturer: Radwag, model: Max 50/1/WH) and resistance grain moisture meter with sample fragmentation (manufacturer: Dramański, model: Grain Master GMS). The third measurement of water content in examined samples was performed using Omega $\mathrm{G}$ analyzer (manufacturer: Briuns Instrument) using near infrared radiation NIR (Dz.U. 2004.20.178).

The fat content in seeds was also measured with Omega $G$ analyzer for rapid and accurate analysis of whole seeds applying NIR technique as well as Instalab 700 analyzer that measures the test material using near infrared NIR-T. This device also allows to determine the protein content in seeds.

Analysis of the seed size, the quantity of contaminants, and seed injuries, was carried out in accordance with PN-R-66160 (1991) by distinguishing between useful (injury, moldy) and useless (organic impurities, stem fragments, etc.) as well as was based on a random sample of 1000 seeds, for which measurements were made in triplicate for each of the three samples. Sieve analysis used shaker (manufacturer: Multiserw-Morek, model: LPzE-2e) and a set of sieves with mesh diameters: 3.00, 2.00, 1.00, 0.50, and $0.315 \mathrm{~mm}$. Particle size analyzer was used (manufacturer: KAMIKA, model: AWK 3D) equipped with an electronic measuring unit with two independent lanes measuring particle size distribution also including meter. The dosing seeds system transmits the analyzed 
material to the vibrating chute with a variable vibration amplitude regulated by an electric motor and ultrasound power.

The test results were processed using AWK 3D software applying Zingg classification based on the proportions between three seed dimensions related to the longest dimension - length (a), medium (b) - width, and the shortest (c) - thickness. It was assumed that:

- $\quad$ Seeds with proportions $b / a>0.67$ and $c / b>0.67$ recall sphere. For $b / a=c / b=1$, it is an exact sphere,

- $\quad$ Seeds with proportions $b / a>0.67$ and $c / b<0.67$ recall disc,

- $\quad$ Seeds with proportions $b / a<0.67$ and $c / b>0.67$ recall rod,

- $\quad$ Seeds with proportions $\mathrm{b} / \mathrm{a}<0.67$ and $\mathrm{c} / \mathrm{b}<0.67$ recall blade.

The tests were performed in triplicate and then arithmetic means were calculated. The statistical analysis was carried out using Statistica 10 software using T-Student test and calculating standard deviations.

\section{RESULTS}

Results of the sieve analysis are shown in Tables 1 and 2. The sieve analysis isolates five seed fractions of different sizes. Referring to the sieve analysis carried out on a shaker with $0.315 \mathrm{~mm}$ mesh, there were no rape seeds but impurities in a form of fine particles after harvesting. Sieve of $0.5 \mathrm{~mm}$ mesh in addition to the contaminants isolated single seeds. The highest percentage of seeds of all cultivars tested was observed on a sieve with the mesh size of $2 \mathrm{~mm}$, which retained the largest amount of Bellevue cultivar $(94.71 \%)$. For Abacus and Adriana+Catana cultivars the results were comparable (approximately $75 \%$ ). According to the analysis carried out using AWK analyzer, it can be concludes that there was no seed fraction which remained on the sieve of less than $0.315 \mathrm{~mm}$ mesh in all three cases. Presence of impurities and individual seeds was also noted on a sieve of $0.5 \mathrm{~mm}$ mesh. The largest share in samples of evaluated cultivars was made up by seeds larger than $1 \mathrm{~mm}(13.68 \%$ to $55.55 \%)$ and larger than $2 \mathrm{~mm}(49.06 \%$ to $85.95 \%)$. Share of other fractions was negligible. The statistical analysis aimed at comparing the two methods showed statistically significant differences between both methods for all three rapeseed cultivars in groups of sieve having $2 \mathrm{~mm}$ and $1 \mathrm{~mm}$ mesh (Table 1). Values in cultivars Bellevue and Adriana+Catana were not taken into account due to the absence of seeds on the $0.315 \mathrm{~mm}$ sieve.

Significantly greater share of seeds were observed in traditional method on $2 \mathrm{~mm}$ mesh sieve than in the IR method. In the case of sieves having $1 \mathrm{~mm}$ mesh, it was observed an inverse relationship with larger seed shares in IR method rather than the traditional method (Table 2). This phenomenon can be explained by a more accurate threedimensional measurement of seeds in the case of the IR method. In traditional method the measurement is carried out only in two dimensions. Therefore, depending on the setting of seeds passing through the screen, there is the possibility of passing a material with different shape than a sphere. This situation can cause a remarkable measurement error when using the traditional method (sieve). Based on this the total volume of seeds and maximum dimension were calculated. Table 3 shows the distribution of rape seeds shape as percentage distribution seeds taking into account their shape. The issue of contamination and injuries to the seeds is widely discussed due to its particularly negative impact on technologies for oil production and its subsequent stabilization. This distribution is provided in Table 2, which shows the quantity and percentage of seeds referring to the shape of analyzed material. In all cases the highest share was reported for a spherical shape representing the range from $92 \%$ to $98 \%$, while the smallest - blades 
being presumably a natural product described as the seed contamination (with irregular and unidentified shape) ranging from 0.3 for Abacus to $1 \%$ for Bellevue. These contaminants were within acceptable limits in fat industry for which in the case of raw rapeseed the pollution level should be about $8 \%$, and for technological about $6 \%$. The disc and rod-shaped seeds were considered damaged or halved. The smallest share of these parameters has occurred for Abacus 1.2\%; for Adriana+Catana $4.43 \%$ and $6.45 \%$ for Bellevue cultivar. No moldy seeds were found.

Table 1. Statistical analysis of rape seeds distribution on sieves (a - AWK 3D, b - LPzE-2e)

\begin{tabular}{|c|c|c|c|c|c|c|c|}
\hline \multirow{2}{*}{ Sieve } & \multicolumn{7}{|c|}{ Statistical parameter } \\
\hline & Mean & Variation & Observations & PPC & Mean difference & $\mathrm{df}$ & t Stat \\
\hline \multicolumn{8}{|c|}{ Abacus } \\
\hline $0.315 \mathrm{a}$ & 0.040 & 7.230 & 3 & -0.84856 & 0 & 2 & -0.65085 \\
\hline $0.315 b$ & 0.123 & 0.045 & 3 & - & - & - & - \\
\hline $1 \mathrm{a}$ & 22.785 & 4.295 & 3 & -0.99705 & 0 & 2 & -8.44171 \\
\hline $1 \mathrm{~b}$ & 49.236 & 11.279 & 3 & - & - & - & - \\
\hline $2 \mathrm{a}$ & 77.158 & 4.293 & 3 & -0.99989 & 0 & 2 & 8.342866 \\
\hline $2 \mathrm{~b}$ & 50.630 & 11.802 & 3 & - & - & - & - \\
\hline \multicolumn{8}{|c|}{ Bellevue } \\
\hline $1 \mathrm{a}$ & 50.058 & 85.753 & 3 & 1 & 0 & 2 & 9.461749 \\
\hline $1 \mathrm{~b}$ & 5.058 & 0.857 & 3 & - & - & - & - \\
\hline $2 \mathrm{a}$ & 94.716 & 0.980 & 3 & -0.28367 & 0 & 2 & 2.842431 \\
\hline $2 b$ & 88.063 & 13.398 & 3 & - & - & - & - \\
\hline \multicolumn{8}{|c|}{ Adriana+Catana } \\
\hline $1 \mathrm{a}$ & 24.161 & 0.759 & 3 & 0.963104 & 0 & 2 & -9.08512 \\
\hline $1 \mathrm{~b}$ & 38.980 & 13.356 & 3 & - & - & - & - \\
\hline $2 \mathrm{a}$ & 75.721 & 0.760 & 3 & 0.97015 & 0 & 2 & 8.376323 \\
\hline $2 \mathrm{~b}$ & 60.680 & 15.595 & 3 & - & - & - & - \\
\hline
\end{tabular}

Table 2. Percentage distribution of rape seeds on sieves using LPzE-2e shaker and AWK 3D analyzer

\begin{tabular}{|c|c|c|c|c|c|c|c|c|c|c|c|}
\hline $\begin{array}{c}\text { Sieves } \\
(\mathrm{mm}) /\end{array}$ \\
\begin{tabular}{c} 
Cultivar \\
\cline { 2 - 11 }$y$
\end{tabular} & 0.315 & 0.50 & 1.0 & 2.0 & 3.0 & 0.315 & 0.50 & 1.0 & 2.0 & 3.0 \\
\hline Abacus & $\begin{array}{c}0.006 \\
\pm 0.05\end{array}$ & $\begin{array}{c}0.001 \\
\pm 0.05\end{array}$ & $\begin{array}{c}26.1 \\
\pm 20.74\end{array}$ & $\begin{array}{c}73.8 \\
\pm 19.99\end{array}$ & $\begin{array}{c}0.04 \\
\pm 0.09\end{array}$ & 0 & $\begin{array}{c}0.01 \\
\pm 0.02\end{array}$ & $\begin{array}{c}49.2 \\
\pm 3.3\end{array}$ & $\begin{array}{c}50.63 \\
\pm 3.4\end{array}$ & $\begin{array}{c}0.37 \\
\pm 0.2\end{array}$ \\
\hline Bellevue & 0.005 & 0.15 & 5.06 & 94.71 & 0.069 & 0 & 0.02 & 11.73 & 85.95 & 0.35 \\
\pm 0.12 & \pm 0.32 & \pm 8.71 & \pm 8.51 & \pm 0.01 & 0 & \pm 0.01 & \pm 3.3 & \pm 3.6 & \pm 0.2 \\
\hline $\begin{array}{c}\text { Adriana+ } \\
\text { Catana }\end{array}$ & $\begin{array}{c}0.01 \\
\pm 0.06\end{array}$ & $\begin{array}{c}0.09 \\
\pm 063\end{array}$ & $\begin{array}{c}24.16 \\
\pm 9.26\end{array}$ & $\begin{array}{c}75.72 \\
\pm 9.88\end{array}$ & $\begin{array}{c}0.02 \\
\pm 0.02\end{array}$ & 0 & $\begin{array}{c}0.02 \\
\pm 0.01\end{array}$ & $\begin{array}{c}38.98 \\
\pm 3.6\end{array}$ & $\begin{array}{c}60.68 \\
\pm 3.9\end{array}$ & $\begin{array}{c}0.37 \\
\pm 0.3\end{array}$ \\
\hline
\end{tabular}

Table 3. Distribution of rape seeds shape using AWK 3D analyzer: b/a $=0.67 ; \mathrm{c} / \mathrm{b}=0.67 ; \mathrm{c} / \mathrm{a}<0.33$

\begin{tabular}{|c|c|c|c|c|c|c|c|c|}
\hline \multicolumn{3}{|c|}{ Abacus } & \multicolumn{3}{|c|}{ Bellevue } & \multicolumn{3}{c|}{ Adriana+Catana } \\
\hline Shape & $\begin{array}{c}\text { Quantity } \\
(\mathrm{pcs})\end{array}$ & $\%$ & Shape & $\begin{array}{c}\text { Quantity } \\
(\mathrm{pcs})\end{array}$ & $\%$ & Shape & $\begin{array}{c}\text { Quantity } \\
(\mathrm{pcs})\end{array}$ & $\%$ \\
\hline Sphere & 978 & 98.49 & Sphere & 919 & 92.55 & Sphere & 941 & 94.67 \\
\hline Disc & 6 & 0.6 & Disc & 41 & 4.13 & Disc & 26 & 2.62 \\
\hline Rod & 6 & 0.6 & Rod & 23 & 2.32 & Rod & 18 & 1.81 \\
\hline Blade & 3 & 0.3 & Blade & 10 & 1.01 & Blade & 9 & 0.91 \\
\hline
\end{tabular}

This distribution can be also presented by graphic form using the Zingg classification. The classification is based on the proportions between three dimensions of seeds by means of a quantitative system. Figures 1 shows the distribution for one of three cultivars (Abacus), dividing the analyzed material into four basic classes: spheres located in the upper right corner of the graph, discs in the upper left corner, rods classified in the lower right corner and blades having unidentified shape of contaminants 
in the lower left corner of the graph.

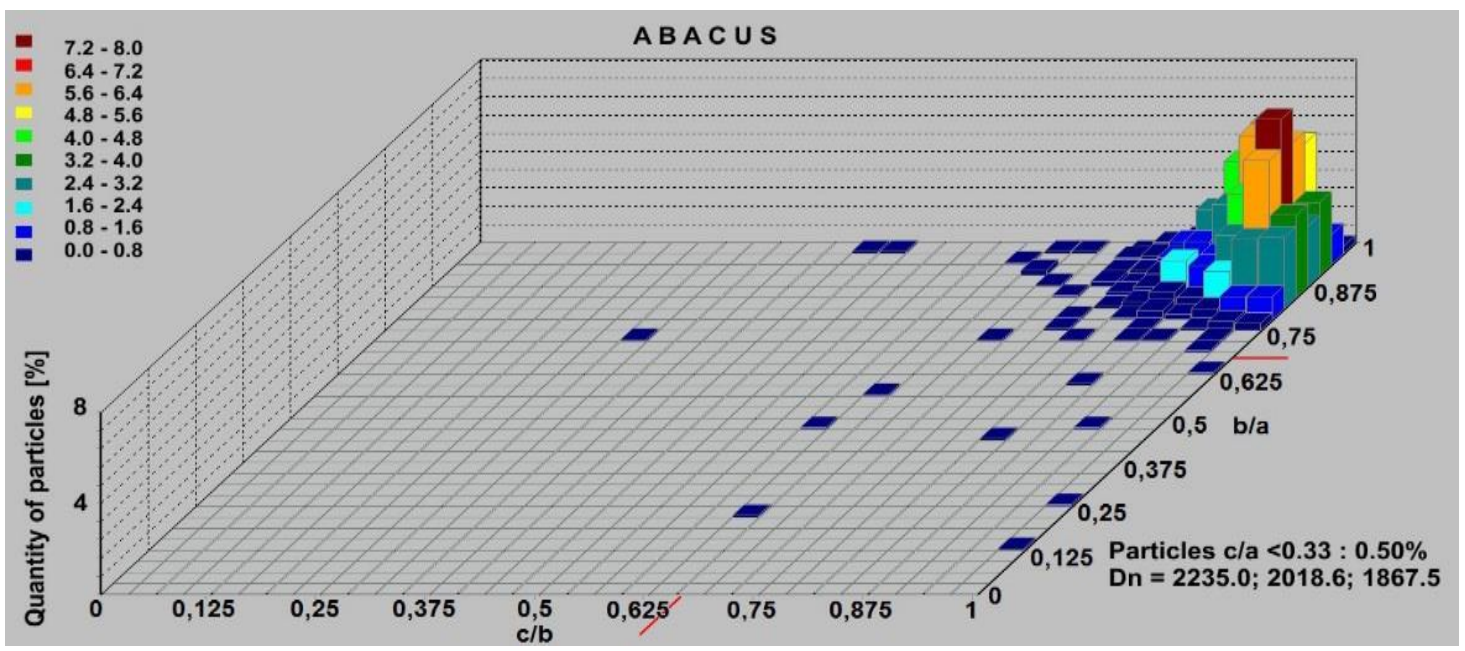

Figure 1. Quantitative distribution of rape seed particles according to Zingg classification for Abacus cultivar

Many farms and fat processing plants use electronic devices to allow rapid analysis of one or more parameters of seed quality. To determine the percentage concentration of such constituents as water, protein or fat, the reflective or transmissive in near infrared (NIR) analysis or in cases where moisture of portable instruments for obtaining fast results, may be used. Table 4 shows the results of rapeseed moisture measurement using three different devices. The samples of rapeseed revealed water content at the level between $6 \%$ and $6.5 \%$ for the moisture meter Dramiński, between $6.2 \%$ and $7.3 \%$ for moisture analyzer and $6.2 \%$ to $7.2 \%$ for Omega G. All tested seeds were characterized by optimal moisture acceptable for Fat Processing Plant in a range of 6-9\% (Szczoła, 2006). Statistical analysis of the moisture results for analyzed rape seeds samples showed no statistically significant differences between used methods of moisture content measurements.

Table 4. Results of protein, fat and moisture content in rapeseed for three cultivars

\begin{tabular}{|c|c|c|c|c|c|c|}
\hline \multirow{2}{*}{$\begin{array}{c}\text { Cultivar / } \\
\text { parameter }\end{array}$} & \multirow{2}{*}{$\begin{array}{c}\text { Protein } \\
{[\%]}\end{array}$} & \multirow{2}{*}{$\begin{array}{c}\text { Fat }- \\
\text { OMEGA G }\end{array}$} & \multirow{2}{*}{$\begin{array}{c}\text { Fat }-700 \\
{[\%]}\end{array}$} & & \multicolumn{3}{|c|}{ Moisture [\%] } \\
\cline { 5 - 7 } & & & OMEGA G & $\begin{array}{c}\text { dryer - } \\
\text { weight }\end{array}$ & $\begin{array}{c}\text { dryer - } \\
\text { Dramański }\end{array}$ \\
\hline Abacus & 20.40 & 43.87 & 45.23 & 7.20 & 6.98 & 6.50 \\
\hline Bellevue & 21.90 & 42.63 & 44.60 & 7.40 & 7.35 & 6.20 \\
\hline Adriana+Catana & 22.30 & 44.00 & 44.53 & 6.20 & 6.19 & 5.97 \\
\hline
\end{tabular}

Table 2 shows also results of fat and protein contents in different rapeseed cultivars. The lowest protein content characterized Abacus cultivar - 20.4\%, and the highest the hybrid Adriana+Catana $-22.3 \%$. The level of fat determined using a near infrared showed values in the range from $43.0 \%$ to $44.5 \%$ for Omega $\mathrm{G}$ and from $44.5 \%$ to $45.0 \%$ for Instalab 700. For fat content values using two devices and for three rapeseed cultivars, statistical analysis showed no significant differences.

\section{CONCLUSIONS}

The use of spectroscopy in the infrared NIR and IR is becoming an increasingly popular method enabling rapid determination of the basic parameters of the chemical composition, both in industrial analytics and research. There are no specific contraindications for the use and preparation of models (samples) for qualitative and quantitative analysis using these spectra. 
Based on the performed analyses, it can be concluded that:

1. Statistically significant differences resulting from different measurement systems between results obtained by means of sieve methods and infrared (IR) were observed. A three-dimensional way of measuring the seed shape used in AWK suggests that it is more accurate than the measurement applying two-dimensional method used in the shaker with a set of sieves.

2. All tested cultivars were characterized by optimum moisture contents ranging within $6.0-7.5 \%$. The greatest differences were found for results in the case of resistance method of moisture which was damaging for seeds.

3. The largest amount of contaminants and damaged seeds were noted in Bellevue and Adriana+Catana cultivars which amounted to $7.45 \%$ and $5.34 \%$ respectively.

4. The highest percentage share of rapeseeds for all cultivars was observed on sieve with $2 \mathrm{~mm}$ of mesh, that collected largest quantity of Bellevue seeds $(94.71 \%)$.

\section{REFERENCES}

Calderini D.F., Slafer G.A. (1998) Changes in yield and yield stability in wheat during the 20th century. Field Crops Res. (57), 335-347.

Casséus, L. (2009) Canola: a Canadian success story. Component of Statistics Canada Catalogue, 96325, http://www.statcan.gc.ca/ (accessed 12.10.10).

Dz.U.2004.20.178. Rozporządzenie Ministra Gospodarki, pracy i polityki społecznej z dnia 22 stycznia 2004r. w sprawie wymagań metrologicznych, którym powinny odpowiadać wilgotnościomierze do pomiaru wilgotności ziarna zbóż i nasion oleistych.

Kachel-Jakubowska, M., Szpryngiel, M. (2006) Jakość surowca ocenianego na podstawie stopnia uszkodzenia nasion rzepaku. Inżynieria Rolnicza, (13), 155-165.

Krasucki W., Tys J., Szafran K., Rybacki R., Orlicki Ł. 2002. Wpływ różnych temperatur suszenia nasion rzepaku na ich skład chemiczny. Rośliny Oleiste, XXIII (2), 428-438.

Nesi N., Delourme R., Bregeon M., Falentin C., Renard M. (2008) Genetic and molecular approaches to improve nutritional value of Brassica napus L. seed. Comptes Rendus Biologies, 331 (10), 763-771. DOI: 10.1016/j.crvi.2008.07.018.

Silvestein R. M., Webster F. X., Kiemle D. J. (2005) Spectrometric Identification of Organic Compounds. Copyright for the Polish edition by WN-PWN SA. Warszawa 2007.

Sujak, A., Kachel-Jakubowska, M. 2012. Effect of Storage Period on Physicochemical Properties of Rapeseeds and Oil. Pol. J. Environ. Stud., 21 (3), 719-723.

Szczoła, J. (2006) Good seed-good yield, good rapeseeds the shooter. Rape - biofuels. A Guide for Producers. Business Press, Warsaw.

Vredenbregt M. J., Caspers P. W. J., Hoogerbrugge R., Barends D. M. (2003) Choice and validation of near infrared spectroscopic application for the identity control of starting materials. Practical experience with the EU draft Note for Guidance on the use of near infrared spectroscopy by the pharmaceutical industry and the data to be forwarded in part II of dossier for marketing authorization. Eur. J. Pharm. Biopharm., 56 (3), 489-499. 